Original Paper http://ajol.info/index.php/ijbcs http://indexmedicus.afro.who.int

\title{
Analyse comparative de la soutenabilité des méthodes d'exploitation de Prunus africana (Hook. f.) Kalkman en vigueur au Cameroun : incidence biologique et socio-économique
}

\author{
E. WETE ${ }^{1}$, J.L. BETTI ${ }^{1}$, J.R. NGUEGUIM ${ }^{2 *}$, Siegfried D. DIBONG ${ }^{1}$ et \\ N.O.F. NJUKOUYOU ${ }^{1}$ \\ ${ }^{1}$ Faculté des Sciences, Département de Biologie et physiologie des organismes végétaux. Université de Douala. \\ BP 24 157. Douala-Cameroun. \\ ${ }_{2}^{2}$ Institut de Recherche Agricole pour le Développement (IRAD), Agence de Liaison, BP 4113. Douala- \\ Bonanjo. Cameroun. \\ *Auteur correspondant ; E-mail : njules_romain@hotmail.com, Tel : 00237677759062
}

\section{RESUME}

Prunus africana (Hook. f.) Kalkman est une plante de haute valeur médicinale qui connait de forte pression d'exploitation au Mont Cameroun. Dans le cadre d'une récolte durable des écorces, deux méthodes d'exploitation (2/4 et 4/8 opposées) ont été recommandées par l'Agence National de Développement des Forêts (ANAFOR) qui est l'autorité scientifique CITES du Cameroun. Cette étude porte sur l'analyse de la soutenabilité biologique et économique de ces méthodes de récolte en vigueur Cameroun. Un inventaire d'exploitation au taux de sondage de $100 \%$ dans une parcelle de 100 ha en fin de première rotation (cycle de 5 années), a servi à la collecte des données sur l'état de santé des arbres (mort, vivant, dépérissant), la mesure des diamètres à hauteur de poitrine et le dénombrement de la population d'arbre. Au total 170 arbres ont été dénombrés, ce qui correspond à 1,7 tiges/ha. Dans cet échantillon on compte 84 arbres (54\%) exploités à la méthode 4/8. Ce groupe comprend 23 arbres dépérissant (27,40\%), 7 arbres morts (8,30\%) et 54 arbres vivants $(64,30 \%)$. Tandis que sur un effectif de 86 arbres (56\%) exploités par la méthode 2/4 on a observé 12 arbres dépérissant (14\%), aucun arbre mort et 74 arbres vivants $(86 \%)$. Ces informations montrent que la méthode d'écorçage (4/8) est plus compromettante sur la croissance des populations d'arbre. Elle est également économiquement la moins rentable avec des pertes de 1650 \$US comparée à la méthode 2/4 (660 \$). La méthode 2/4 a un faible impact sur la santé des arbres, elle peut être améliorée et adoptée comme méthode de récolte durable qui garantit une cicatrisation rapide de l'écorce des arbres et des revenues importants.

(C) 2020 International Formulae Group. All rights reserved.

Mots clés : Plante médicinale, méthode de récolte durable, régénération, aménagement des ressources forestières, Mont Cameroun.

\section{Comparative analysis of the sustainability of prunus africana (Hook. f.) Kalkman harvesting techniques used in Cameroon: biologic and socioeconomic incidence}

\begin{abstract}
Prunus africana (Hook. f.) Kalkman is a medicinal plant with a high socioeconomic value which is facing serious bark harvesting pressure in Mount Cameroon. To ensure sustainable exploitation, two norms (2/4 and 4/8 opposites) was prescribed by the National Forestry Agency (ANAFOR) which is the CITES scientific authority in Cameroon. This study analyzes the biologic and economic sustainability of these harvesting practices. Data
\end{abstract}


collection consisted of trees inventory, measurement of trees diameter and appreciation of tree vitality within a 100 ha plot at the end of the first rotation (five years later after bark harvesting). The sample comprise 170 trees (corresponding to 1.7 trees/ha) amongst which 84 trees (54\%) were harvested using 4/8 technic. In this group, $23(27.40 \%)$ trees were found in bad health, $7(8.30 \%)$ trees dead, 54 trees alive $(64.30 \%)$ and the annual diameter increment was $0.42 \pm 0.37 \mathrm{~cm}$ while in a group of 86 trees $(56 \%)$ harvested with $2 / 4$ technic, observation shown: 12 trees $(14 \%)$ in bad health, 74 trees alive $(86 \%)$ and annual diameter increment of $0.44 \pm 0.36 \mathrm{~cm}$. This statistic shows that, $4 / 8$ technic has a negative impact on trees population and is less benefit with losses estimated at 1650 \$US comparing to 660 \$US (2/4 technic). The 2/4 technic can be improved and adopted as a suitable harvesting method; since it ensures a fast diameter recovery, low impact on trees population and generate more income.

(C) 2020 International Formulae Group. All rights reserved.

Keywords: Medicinal plant, sustainable harvesting techniques, regeneration, forest resources management, Mount Cameroon.

\section{INTRODUCTION}

Cameroon's forest ecosystems are rich and diverse with more than 8,260 plant species that includes nearly 150 endemic species ranking the country second in Central Africa after the DRC (WCMC, 2000). These forest products are exploited daily by rural communities to meet their subsistence needs and by the Government to improve the national economy. According to forest law, forest products consist mainly of ligneous and nonligneous plant products, as well as wildlife and fisheries resources. For many years, forest resources management in Cameroon has been focusing on trees and fauna, rather than nontimber forest products (NTFPs) e.g. $P$. africana. Despite this situation, the NTFPs sector remains one of the most important in rural areas (FAO, 2009). Past studies have shown that the barriers to sustainable management of NTFPs include ecological and biological constraints. Since the 1990s, there has been a renewed interest and awareness among Congo Basin countries and donors, about the role of non-timber forest products (NTFPs) in rural area of Central Africa in particular and the world in general. Indeed, more than half of the rural population in central Africa are dependent on NTFPs for food, treatment and income (Kamga et al., 2018; Unaeze et al., 2013; Dkamela, 2001). NTFPs raise high economic value and create jobs in a large scale. Dynamic markets exist at the local, regional and international levels. Meanwhile in production areas, there is lack or an underrepresented statistic at national level of NTFPs harvesting. At least 570 plants and 110 animal species are used as NTFPs. The market value of 45 major NTFPs traded in Cameroon, including bush meat, fish, firewood and plant products, is estimated at about $\$ 1,028,000,000$ per year. Some of these products like $P$. africana, are under threat of extinction in their natural milieu due to overexploitation (CIFOR, 2010). Cameroon's awareness of the existence of many forms of competitive pressure on forest resources has led the country to adhere to various international conventions. This awareness includes the Convention on International Trade in Endangered Species of Wild Fauna and Flora (CITES), the Convention on Biological Diversity (CBD) and the adoption of new laws that regulate forest activity, namely Law No. 94/01 of 20 January 1994 on Forest, Wildlife and Fisheries follow by his application decree No. 95/531/PM of 23 august 1995, as well as basic texts and decisions to regulate the management of forest products (FAO, 2009).

$P$. africana is a tree species whose product is sought at the level of the bark. The bark is dried and crushed that is the basic ingredient for the industrial manufacture of drugs against prostate disorders. In the traditional health system, leaves, bark and roots are commonly used in the treatment of stomach ache, malaria and fever. In addition, Ndam and Ewusi (2000) report that the bark of $P$. africana 
mixed with other plant-derived products such as Trechillia sp. and Olea capensis can treat syphilis. The bark of $P$. africana is marketed in Cameroon and exported to some European countries, such as France, Belgium, Spain and Italy (Ndam and Ewusi, 2000). A part from their use as medicinal plants, the tree also offers ecosystem services. This species is increasingly sought in agroforestry research programs in the Congo Basin countries of Cameroon and is being studied for large-scale domestication. Cameroon's production of this species represents $2 / 3$ of the world market and comes mainly from Mount Cameroon. In 1999, the contribution of $P$. africana to the Cameroonian economy was estimated at $\$$ 700,000 (Tassé, 2006). The bark of P. africana is subject to a significant national and international trade, the demand is constantly increasing. Some poor practices such as tree felling or total stripping of bark from the main stem to small branches in forests have led to international preventive measures (Tonye et al., 2000). Thus, in 1995, $P$. africana was included in Annex II of the Convention on International Trade in Endangered Species of Wild Fauna and Flora (CITES). As a result of these irregularities, a conference was organized by CITES in Lima, Peru, in September 2008 with a view to decide on the management methods of $P$. africana in exporting countries. During this conference, some States, like Cameroon, were asked to stop exporting $P$. africana from 31 December 2008, to draw up an inventory of the resource and produce a management plan. Failure to comply with this recommendation would result in a trade embargo against these countries (Ingram et al., 2009). The deficiencies noted in Cameroon obliged European Union (EU) to suspend the country's exports in 2008. This resumed two years later after the first management inventory results which led to the development of a nondetriment finding document in the production basins, the North western, South western and Adamaoua regions, (Belinga, 2011). Cameroon was granted an annual quota of about $630 \mathrm{t}$ of $P$. africana dry bark in 2011 that was distributed as follows: North West (150 t), South West $(170 \mathrm{t})$ and Adamaoua (350 t) (Tchouto et al., 2014). In the South-West region, authorities of Mount Cameroon National Park have as a precautionary measure to reduce the quota to $130 \mathrm{t}$ while maintaining the rotation at 5 years. Harvests started in 2011 as part of a tripartite agreement that unites the forest administration represented by the conservation services of Mount Cameroon Park, the confederation of communities bordering Mount Cameroon known as GIC MOCAP, and economic operator AFRIMED (Eben, 2011).

In view of the ever-increasing interest in this species due to its medicinal and socioeconomic interest that leads to inappropriate exploitation techniques (cutting of trees, total debarking); consequently, norms for sustainable bark harvesting have been defined (2/4 and 4/8 opposites). Several years have passed and poor debarking practices continue to be decried. Today, we can question the efficiency, profitability and sustainability of these harvesting norms. Hence, the objective of this study that entails a comparative analysis of the two $P$. africana harvesting norms used in Mount Cameroon forest.

\section{MATERIALS AND METHODS \\ Study site}

The study area is situated in Mount Cameroon, in the Southwest Region (Figure 1). It covers $25,000 \mathrm{~km}^{2}$ between the departments of Fako and Meme $\left(3^{\circ} 57^{\prime}-4^{\circ} 27^{\prime} \mathrm{N}\right.$ and $8^{\circ} 58^{\prime}-$ $\left.9^{\circ} 24^{\prime} \mathrm{E}\right)$. Mount Cameroon is also called Mount Fako. It is the highest mountain in Central and West Africa, with the peak at over $4095 \mathrm{~m}$ (Ondigui, 2001). It covers the Mount Cameroon National Park, the Buea Communal Forest and some community forests (Etindé, Woteva and Bakingili). The Mount Cameroon forest has five blocks spread over 32, 868 ha. The data collected in this study covers a 100 ha parcel of Block 1 with a total area of 3, 691 ha. The months of january and february are the 
hottest with $30{ }^{\circ} \mathrm{C}$ of temperature and the coolest months are march and april $\left(14{ }^{\circ} \mathrm{C}-15\right.$ $\left.{ }^{\circ} \mathrm{C}\right)$. The vegetation in this zone is characterized by the presence of Agauria sp., Gnidia glauca, Crassocephalum mannii, Maesa lanceolata, Philippia mannii, Nauxia congesta, Ficus elastica, Hypericum sp., Syzygium staudtii. Several species of ferns, mosses, lichen and orchids grow on the trunks of trees which highlight the very wet nature of the forest.

\section{Plant material: Description, use and socio-} economic importance of $P$. africana (Rosaceae)

P. africana is still known as "African Cherry" in English and "Prunier d'Afrique" in French. The local names vary with the localities: "Wotango" in Bakweri, "Kanda stick" in Pidgin, "Alumty" in Ngemba, "Vla" in Oku, "Kirah" in Banso and "Dalehi" in Fulfulde (Cunningham and Mbenkum, 1993; Takere, 2001). This species is found in about 20 countries in sub-Saharan Africa (Angola, Burundi, Cameroon, Democratic Republic of Congo, Equatorial Guinea, Ethiopia, Kenya, Lesotho, Madagascar, Mozambique, Rwanda, Sao Tome and Principe, South Africa, Sudan, Swaziland, United Republic of Tanzania, Uganda, Zambia and Zimbabwe (CITES, 2006). It is a large tree of mountainous regions in tropical Africa reaching 30 to $40 \mathrm{~m}$ height that grows above $700 \mathrm{~m}$ altitude. In Cameroon, there are three production basins (North-West, South-West and Adamaoua), and for a very long time Mount Cameroon (South-West) has supported most of the national production. Other mountains such as Mount Kupe, Mount Oku, Tchabal Mbabo and all the high mountain range of the North-West are now exposed to mining exploitation (ONADEF, 2000). It is established that $P$. africana bark is the basic material for the industrial manufacture of drugs for prostate disorders. Prostate cancer is responsible for $10 \%$ of cancer-related deaths in general, making it the second leading cause of cancer death among men and the fourth most fatal cancer. Cameroon is the largest exporter of the bark of $P$. africana with an average of 1,500 tons of fresh bark. This value reached 2,000 tons in the year 1990 (Cunningham et al., 2002). Cameroon's production accounts for $2 / 3$ of the world market and comes mainly from Mount Cameroon (Tassé, 2006). Its wood is used in building construction and sculpture. It is also used for the manufacture of mortar and tool handle (hoe, axe). It is also a real source of energy in rural areas (Hall et al., 2000).

\section{Description of the current peeling techniques of $P$. africana}

Two $P$. africana debarking techniques are recommended in Cameroon as norms and used in the production area of Mount Cameroon:

- Technic 2/4 is applied to trees whose diameter at $1.30 \mathrm{~m}$ from the ground is between 30 and $60 \mathrm{~cm}$. It consists in segmenting the trunk into four equidistant longitudinal strips. Two opposite strips are barked each having a width of $15 \mathrm{~cm}$ so that each strip debarked will be separated from the next by an unboned strip. The remaining two opposite bands must each have a width of at least $15 \mathrm{~cm}$.

- The 4/8 technic concerns trees with a diameter of more than $60 \mathrm{~cm}$ measured at 1.30 $\mathrm{m}$ from the ground. It consists of dividing the trunk into eight equal vertical bands. The debarking is practiced on four opposite bands in pairs so that each debarked strip is separated from its neighbour by an unboned strip.

\section{Methods}

An inventory was done in 2018, over a 100 ha plot harvested in 2013; thus making it five years that is equivalent to one rotation (ONADEF, 2000). The layouts defined by the survey design have been materialized at the base by a numbered milestone. Each layout is open over a width of $1.5 \mathrm{~m}$ and marked by an alignment of the milestones spaced $50 \mathrm{~m}$. Along the tracks, the operations concern the systematic counting of all the stems that have already been exploited, the identification of the 
debarking technique $(2 / 4$ or $4 / 8)$, and the verification of the impact of debarking techniques on trees (living tree, dying, dead) according to the recommendations prescribed by the Ministry of Forests and Wildlife of Cameroon (PSMNR-SWR, 2013). Based on the inventory data, the biological and socioeconomic losses were established, using the formulas in force in the management standards. Biological losses are estimated by the formula: $Q_{a}=Q_{h}=P_{b}=N . r$

Where: $Q_{a}=$ harvesting quota. $Q_{h}=$ Quantity or stock of wet bark in $\mathrm{kg} . \mathrm{r}=$ Average yield in $\mathrm{kg}$ / stem $=55 \mathrm{~kg} . \mathrm{N}=$ Total number of trees.
Socio-economic losses and the recovery rate (TR) of stem bark are estimated by the formula: $\mathrm{P}_{\mathrm{b}}=\mathrm{r} \times \mathrm{N}_{\mathrm{d}} \quad \mathrm{P}_{\mathrm{e}}=\mathrm{r} \times \mathrm{N}_{\mathrm{v}} \times \mathrm{p} \quad$ Forecast $=\mathrm{r} \times \mathrm{N} \times \mathrm{p}$

Where: $P_{b}=$ Biological loss, $\mathrm{N}_{\mathrm{d}}=$ Total number of trees falling away and dying, $P e=$ economic loss, $\mathrm{Nv}=$ Total number of living trees, $\mathrm{P}=$ price of one $\mathrm{kg}$ of bark $=1 \$, \mathrm{~N}=$ Total number of trees, $\mathrm{r}=$ Average yield in $\mathrm{kg} / \mathrm{stem}=55 \mathrm{~kg}$. The recovery rate has been estimated for each tree that has already been exploited and calculated using the following formula:

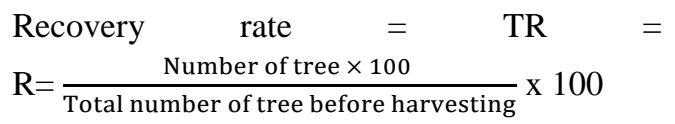

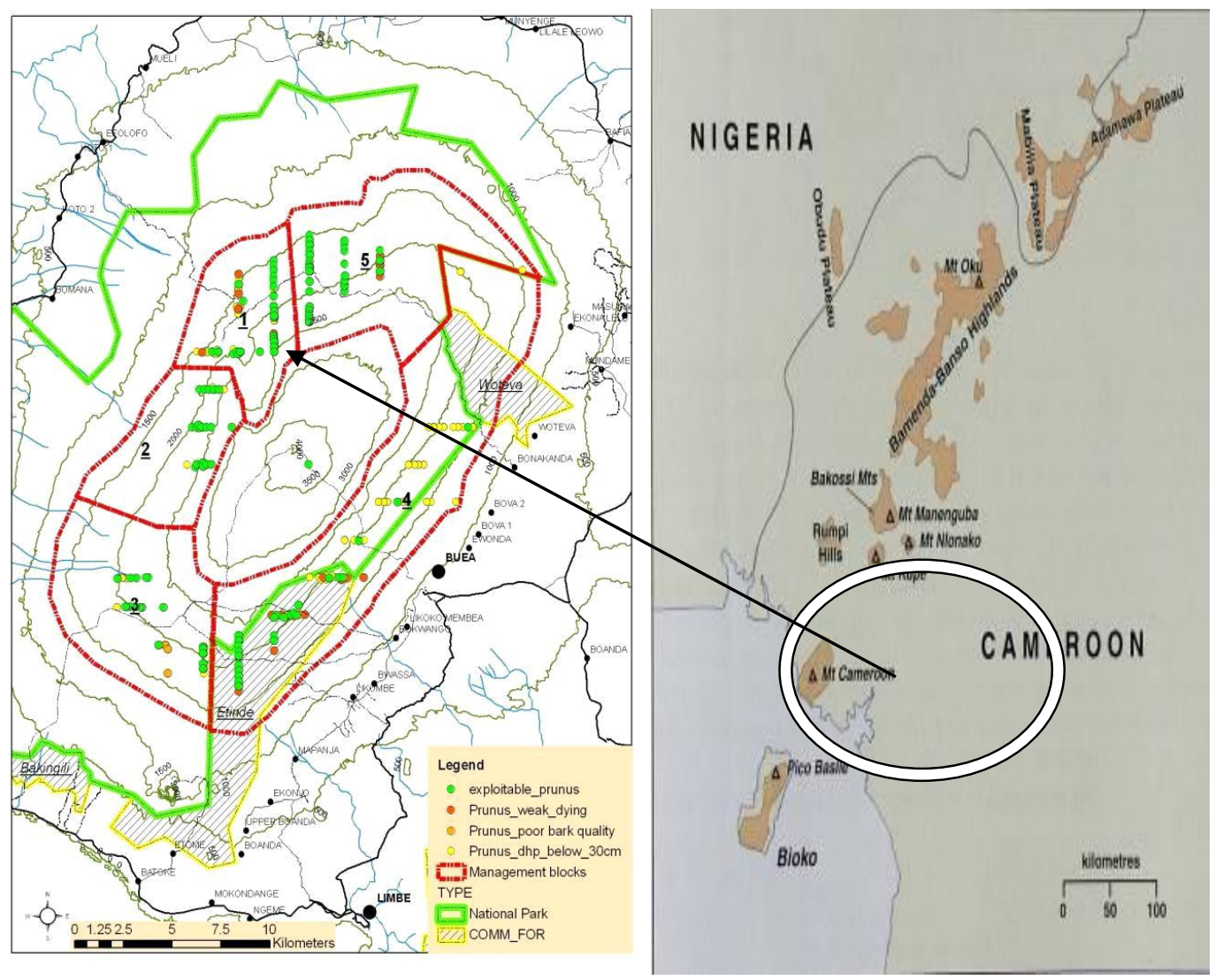

Figure 1: Geographic situation of the studied site in Mount Cameroon. 


\section{RESULTS}

\section{Influence of debarking techniques on growth performance of trees}

A total of 170 trees were counted, which corresponds to a density of $1.7 \mathrm{stems} / \mathrm{ha}$. This number consists of $86(56 \%)$ trees using the $2 / 4$ harvesting technic and $84(54 \%)$ trees using the $4 / 8$ technic. The use of these two techniques resulted in the dieback and death of 42 $(24.70 \%)$ stems that subsequently reduced the density to 1.28 stems/ha. The comparative analysis of the impact of harvesting techniques on the stands shows that the use of the $4 / 8$ method resulted in high mortality or dieback rates $(35.70 \%$ of the population). This value remains low in the $2 / 4$ method (14\%) (Table 1).

\section{Comparative analysis of the impact of harvesting techniques on population structure}

Figure 2 shows the population structure in 2013 before harvesting and five years after harvesting. Before tree harvesting we can observe that the population structure has a regular shape, with abundant numbers of young stems which decrease when the size of trees increases. There is a sudden fall in numbers of trees in the diameter class [60-70]. At the end of a five-year rotation, it can be noted that the harvesting method $2 / 4$, which concerns trees with diameter 30 to $60 \mathrm{~cm}$, could have a strong impact on young trees. This is justified by a significant decrease in numbers of trees in the diameter class [30-40] which would be the combined effect of mortality/dieback and tree recruitment in the higher diameter classes. With regard to the $4 / 8$ method, which concerns trees with more than $60 \mathrm{~cm}$ in diameter, it can be observed that it has a greater impact on trees of diameter [60-70] and large trees (dhp > 140 $\mathrm{cm}$ ), resulting in a possible decline of the population, due to lack of big trees.

\section{Comparative analysis of the Impact of harvesting techniques on bark recovery rate, after a period of five years}

Figure 3 shows the rate of reconstitution of $P$. africana bark based on harvesting techniques. It appears that the recovery rates are greater than $95 \%$ when using $2 / 4$ harvesting method. These reconstitution rates will progressively decrease and present several steps with the use of the $4 / 8$ method. These values are estimated to be $85 \%$ for trees in the diameter classes] $60-100$ ], $70 \%$ for] 100 120], 45\%] 120 - 130] and zero when the diameter is greater than $130 \mathrm{~cm}$.

\section{Analysis of the socioeconomic impact of harvesting techniques}

At the end of the tree inventory operations, there were 7 dead trees and 35 declining trees, totalling 42 trees. This mortality corresponds to a net loss of approximately 1270500 FCFA $(\$ 2,310)$. The losses caused by the $4 / 8$ method $(907500 \mathrm{~F}$ CFA 1650 \$) are approximately three times higher than those obtained by the use of the $2 / 4$ technique (363 000 F FCFA 660 \$) (Table 2).

There is a participative management of $P$. africana in Mount Cameroun. The stakeholders are the conservation service of the Mount Cameroon National Park, local communities association (GIC MOCAP) and economic operators. This approach facilitated the identification of expenditures and the equitable distribution of incomes. Table 3 shows an extract from the $P$. africana exploitation account obtained from the park conservation department. It can be estimated that the forecast was $\$ 9350(5142500 \mathrm{~F}$ CFA), but only $\$ 7040$ (3 872000 F CFA) was recorded as income. This corresponds to a loss of \$ 2310 (1 270500 F CFA) which represents $28.75 \%$ of forecasts. The communities benefit came particularly from four expenditures: Facilitation, Harvesters and monitoring of trees regeneration. These revenues are spent at the village level and allow maintaining local economy. Also, the "village development" expenditure generates revenue for the implementation of community projects. The losses in these expenditures $\$ 1524.6$ or $19 \%$ of the forecasts seem quite high and likely to affect the key objective of the participatory management concept, which consist to the sustainable management of natural resources and socio-economic development of villages through incomes generated by harvesting of resources. 
Table 1: Impact of harvesting techniques on tree population.

\begin{tabular}{lcccc}
\hline Harvesting techniques & Population & Living trees & Dying trees & Dead trees \\
\hline $2 / 4$ & $86(56 \%)$ & $74(86 \%)$ & $12(14 \%)$ & $0(0 \%)$ \\
\hline $4 / 8$ & $84(54 \%)$ & $54(64.30 \%)$ & $23(27.40 \%)$ & $7(8.30 \%)$ \\
\hline Total & $170(100 \%)$ & $128(75.30 \%)$ & $35(20.58 \%)$ & $7(4.12 \%)$ \\
\hline
\end{tabular}

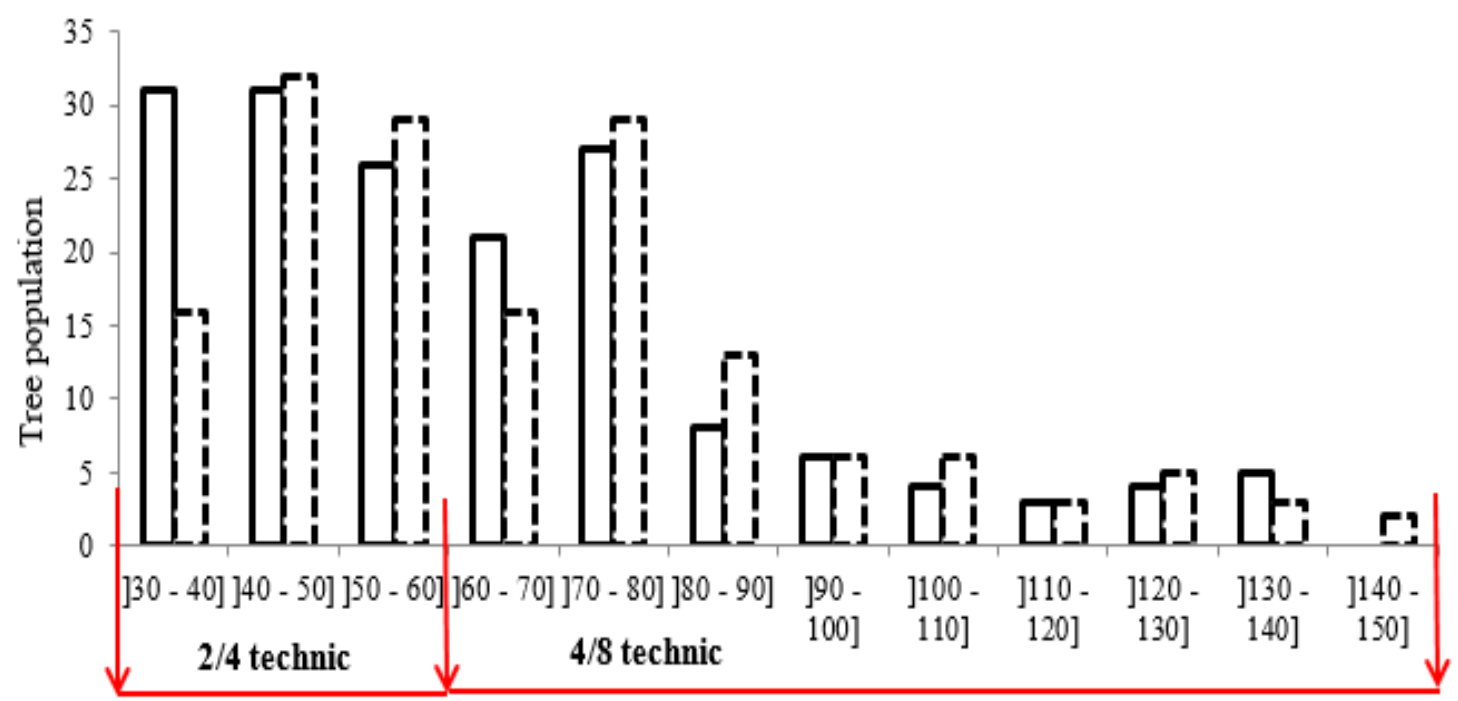

DTree population before harvesting (in 2013) $\quad$ J Tree population 5 years later after harvesting (in 2018)

Figure 2: Diametric structures of tree populations before and five-years later after harvesting.

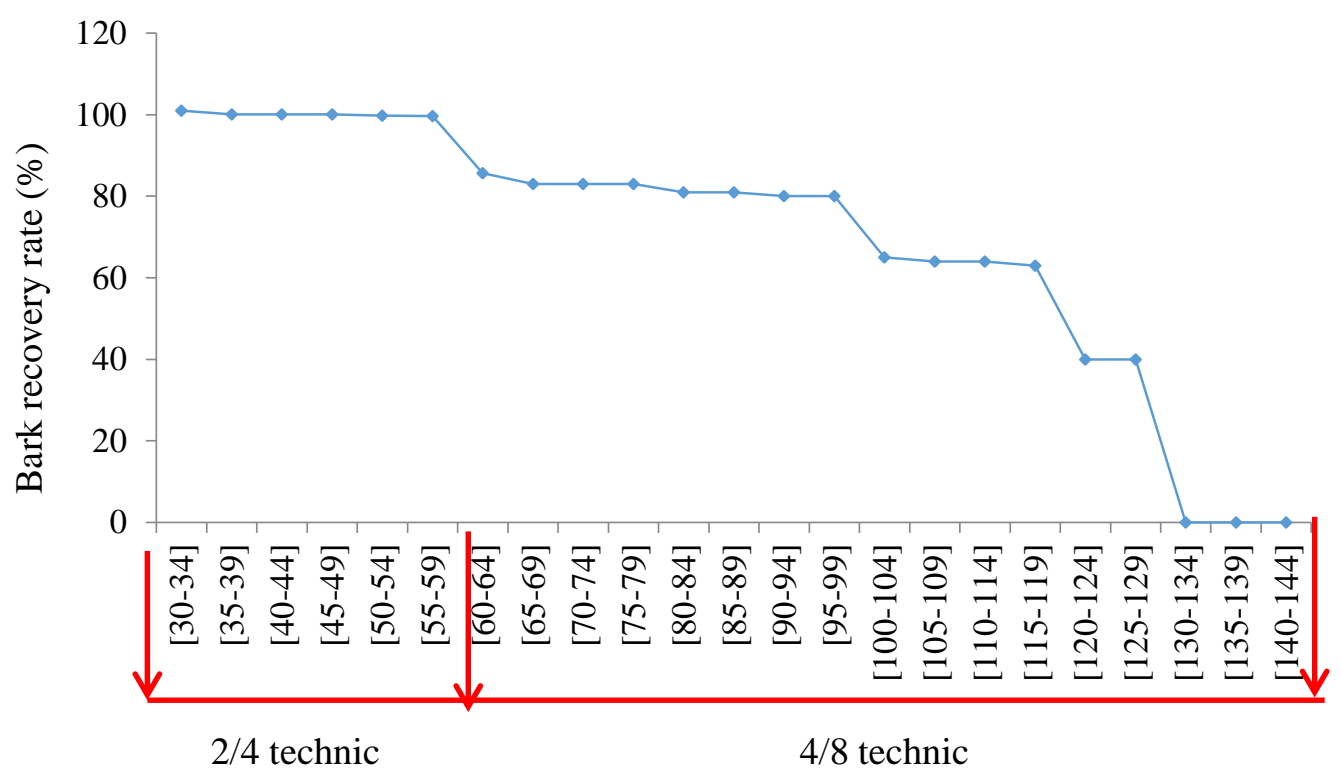

Figure 3: Bark recovery five years after harvesting. 
Table 2: Economic impact of harvesting techniques.

\begin{tabular}{lcccccc}
\hline Techniques & $\mathbf{N}_{\mathbf{t}}$ & Forecast (\$US) & $\mathbf{N}_{\mathbf{v}}$ & Income (\$US) & $\mathbf{N}_{\mathbf{m}+\mathbf{d}}$ & Losses (\$US) \\
\hline $2 / 4$ & 86 & 4730 & 74 & 4070 & 12 & 660 \\
\hline $4 / 8$ & 84 & 4620 & 54 & 2970 & 30 & 1650 \\
\hline Total & 170 & 9350 & 128 & 7040 & 42 & 2310 \\
\hline
\end{tabular}

$\mathrm{N}_{\mathrm{t}}$ : Total number of trees. $\mathrm{N}_{\mathrm{v}}$ : Number of live trees. $\mathrm{N}_{\mathrm{m}+\mathrm{d}}$ : Number of dead trees + dying.

Table 3: Operating account of $P$. africana by the rural communities around Mount Cameroon (source:

Mount Cameroon Conservation Service 2016 - 2017).

\begin{tabular}{lcccccccc}
\hline Expenditures & $\begin{array}{c}\text { Development } \\
\text { of villages }\end{array}$ & $\begin{array}{c}\text { Facilitation } \\
\text { (GIC } \\
\text { MOCAP) }\end{array}$ & $\begin{array}{c}\text { Park } \\
\text { conservation } \\
\text { office }\end{array}$ & Regeneration & Transport & Stoking & Harvesters & Total \\
\hline Quotas (\%) & 16 & 7 & 20 & 7 & 4 & 3 & 43 & $100 \%$ \\
\hline Forecast (\$) & 1126.4 & 492.8 & 1408 & 492.8 & 281.6 & 211.2 & 4020.5 & 8033.3 \\
\hline Incomes (\$) & 756.8 & 331.1 & 946 & 331.1 & 189.2 & 141.9 & 3027.2 & 5723.3 \\
\hline Losses (\$) & 369.6 & 161.7 & 462 & 161.7 & 92.4 & 69.3 & 993.3 & 2310 \\
\hline
\end{tabular}

\section{DISCUSSION}

\section{Debarking techniques of Prunus africana at Mount Cameroon}

This study is conducted on Mount Cameroon over a plot of 100 ha where the two $P$. africana harvesting methods $(2 / 4$ and $4 / 8)$ prescribed in Cameroon by ANAFOR, the CITES Scientific Authority are practiced (Betti et al., 2016, 2019; Yankam, 2013). At the end of a five years' rotation, we observe that out of a total of 170 trees harvested by the two methods of which $86(56 \%)$ trees harvested by the $2 / 4$ technic and 84 trees $(54 \%)$ by $4 / 8$ technic; tree density decreased from 1.7 to 1.28 stem/ha, only $128(75.30 \%)$ trees where alive, 35 trees were dying $(20.51 \%)$ and $7(4.12 \%)$ trees dead. This mortality is more attributed to the $4 / 8$ debarking technic with $35.70 \%$ dying and dead trees compared to $14 \%$ for the $2 / 4$ technic. This difference could be explained by the fact that young trees that are still in full growth phase are more able to recovery than mature trees. This mortality can also be induced by debarking techniques and inappropriate application of techniques by farmers. Tasse (2006) recorded similar results in Mount Cameroon, it indicates a survival rate of $70.53 \%$ and a mortality of $29.47 \%$; while Yankam (2013) on a sample of 3058 trees harvested reveals 5 years later that 2134 trees $(69.9 \%)$ were in good health against 924 $(30.1 \%)$ in bad health and non-exploitable. Dibobé et al. (1999) highlight bad debarking practices in Mapanja where out of 67 trees sampled, it recorded 55 trees felled, 9 trees completely debarked and only 3 trees sustainably harvested. During a baseline study on P. africana at Mount Cameroon, Awono et al. (2015) found that despite good social organization and high level of profitability, annual harvesting quotas decreased from 100 tons to 70 tons due to tree mortality caused by limited application of appropriate harvesting techniques. This drop in quotas has led several authors to believe that debarking techniques that damage tree cambium remains a major 
problem for the survival of species, especially those threatened with extinction, such as $P$. africana (Belinga, 2011; Betti et al., 2010).

\section{Threat on the sustainability of $P$. africana on Mount Cameroon}

The suspension of $P$. africana exportation from Cameroon in 2008 awakens the consciences of decision makers, on the necessity for the sustainable management of the resources. Prior to this date, $P$. africana harvests were unsustainable and characterized by high harvesting pressures. Several inventories on $P$. africana were conducted at Mount Cameroon by ONADEF. Reports indicate that in 1997 about $40 \%$ of exploitable stems were excessively debarked; and in 1999, the use of the Adaptive Cluster Sampling (ACS) methodology showed that $44 \%$ of inventoried trees died by slaughter and $36 \%$ as a result of poor harvesting practices. Tassé (2006) observed in the Bokwaongo - Mapanja area on the slope of Mount Cameroon that $30.15 \%$ of trees had trunk and branches completely debarked; $3.51 \%$ of the trunk completely debarked, $10 \%$ felled down before exploitation and $50 \%$ of trees harvested have not yet reached the Minimum Exploitation Diameter $(\mathrm{DME}=30 \mathrm{~cm})$. This divergence in harvesting practices and income generation explains the anthropogenic pressures which lead to low turnover of the species and decrease of production on Mount Cameroon. The sanction was lifted in 2010, after the development of sustainable harvesting standards (2/4 and 4/8) and restoration of forest ecosystems.

\section{Socio-economic impact of harvesting techniques on the regeneration of the species} According to the operating account of the Mount Cameroon Conservation Department (2016 - 2017), the financial losses for an area of 100 ha of forest are estimated at \$US 2310 (1 270500 F CFA). The 4/8 technic is the least profitable with about the tripe of losses ( $\$$ US $1650 \sim 907500$ F CFA) observed for the $2 / 4$ method. In view of the quotas for the redistribution of income generated by the farm, the share allocated to local development and local labour management is strongly impacted by the harvesting techniques. Betti (2004) and Yankam (2013) observed that depending on bark harvesting methods, average annual earnings per producer can vary in the Southwest from \$US 134.96 (7 422800 F CFA) to \$US 299.63 (16 479650 F CFA). In view of this information, it appears that an unsustainable harvesting method can significantly affect the quality of life of communities that derive income and other livelihoods from the exploitation of $P$. africana.

\section{Conclusion}

At the end of this study on the comparative analysis of the two recommended harvesting practices of $P$. africana in Cameroon, it appears that the $4 / 8$ technic is economically and ecologically less profitable than $2 / 4$. It resulted in high tree mortality and dieback $(35.70 \%)$, especially in large trees; a decreased rate of bark regeneration with the size of trees and about the tripe of losses (\$US 1650) observed for $2 / 4$ method. As $2 / 4$ method concerns young trees in full growth phase (30 $<$ dbh $<60$ ), we observed that, their diameter recovers quickly after harvesting; unlike the 4/8 method which applies to big trees with low diameter increment $(\mathrm{dbh}>60 \mathrm{~cm})$. Losses recorded during harvesting of $P$. africana bark affect farmers' incomes and could lead to the illegal practices observed. For an economically profitable operation that respects the intrinsic regenerative capacity of $P$. africana, we suggest the refinement of the 2/4 technic, the recycling of farmers on the appropriate harvesting methods and use of appropriate debarking tools to minimize damage on tree cambium.

\section{COMPETING INTERESTS}

The authors declare that they have no competing interests.

\section{AUTHORS CONTRIBUTIONS}

EW: Data collection, writing of draft; JLB: Supervisor of the study, funding, project proposal, data collection, correction of manuscript; JRN: Co-supervisor of the study, 
data treatment and analysis, literature, correction and submission of manuscript; SDD, NOFN: Supervisor of the study, correction of manuscript data collection.

\section{AKNOWLEDGEMENTS}

The authors thank all stakeholders including: ANAFOR, the CITES Scientific Authority in Cameroon; Mount Cameroon Conservation Agency which is a decentralized office of the Cameroon Ministry in charge of Forest, the Liaison Agency of the Institute of Agricultural Research for Development (IRAD) in the Littoral Region of Cameroon, local communities AFRIMED and MOCAP leaders for their facilities, active participation, advices and collaboration.

\section{REFERENCES}

Belinga S. 2011. Rapport d'inventaire national de P. africana au Cameroun : étape du Mont Cameroun. Projet OIBT/ CITES « Avis de commerce Non Préjudiciable sur le P. africana au Cameroun ». ANAFOR. $55 \mathrm{p}$.

Betti JL, Fouadjo B, Wété E, Ngueguim JR, Njimbam OF, Tientcheu S, Tchiyip PD. 2019. Monitoring the harvesting of the barks of Prunus africana (Hook.f.) Kalkman (Rosaceae) in the agroforest systems of North-West region of Cameroon. International Journal of Agricultural Policy and Research, 7(3): $55 \quad-69 . \quad$ DOI: https://doi.org/10.15739/IJAPR.19.007

Betti JL, Akoa A, Ewusi NB, Mbarga N, Akagou ZHC, Fonkoua C, Essomba ER, Nkouna AC. 2010. Preliminary report on sustainable harvesting of Prunus africana (Rosaceae) in the North West region of Cameroon. Report prepared for the National Forestry Development Agency (ANAFOR), the Cameroon CITES Scientific Authority for flora, in the frame of the project "Non-detriment findings for Prunus africana (Hook.f.) Kalman in Cameroon", 76 p.

Betti JL. 2004. Politique forestière sur les produits Forestiers Non Ligneux au Cameroun: Vers une maitrise de l'assiette fiscale. Actes de la 5ème Conférence sur les Ecosystèmes des Forêts Denses et Humides d'Afrique Centrale (CEFDHAC). 24-26 Mai. IUCN-ROCA, 348-3566.

CIFOR. 2010. Inventaire de Prunus africana dans les Provinces du Sud-Ouest et du Nord-Ouest du Cameroun. Rapport d'activité. Yaoundé, Cameroun.

CITES. 2006. Etude du commerce important de Prunus africana, White Gum Valley Australie. 33p.

Cunningham AB, Ayuk E, Franzel S, Duguma B, Asanga C. 2002. An economic evaluation of medicinal tree cultivation. People and Plants Working Paper $\mathrm{N}^{\circ} 10$, UNESCO, Paris.

Dkamela GP. 2001. Les institutions communautaires de gestion des produits forestiers non ligneux dans les villages périphériques de la Réserve de Biosphère du Dja. The Tropenbos Cameroon programme, Kribi. Tropenbos Cameroon. Document 7. 72p.

Eben Ebai S. 2011. Prunus africana management plan for the Mount Cameroon National Park and it's support zone. Ministry of forestry and wildlife (MINFOF).

FAO. 2009. Techniques de gestion des écosystèmes forestiers tropicaux : état de l'art. Working paper: FAO/fpirs/05 prepared for the World Bank forest policy implementation review and strategy. FAO, Rome Italie. 146p.

Hall J, O'brien E, Fergus LS. 2000. Prunus africana: A monograph. School of Agriculture and Forest Sciences. Publication number 18, University of Wales, Bangor. 104p.

Höft R, Cunningham T. 2000. Le Réseau Africain d'Ethnobotanique. Revue de la littérature ethnobotanique pour l'Afrique Centrale et l'Afrique de l'Ouest. Bulletin No2.

Ingram V, Awono A, Schure J, Ndam N. 2009. Guidance for a national Prunus africana management plan, Cameroon. CIFOR, FAO. 158 p. 
Kamga YB, Nguetsop VF, Momo SMC, Riera B. 2018. Diversité floristique des ligneux et structure des formations à Garcinia Kola Heckel dans les Régions du Centre et de l'Est, Cameroun. European Scientific Journal Vol. 14, No. 21. http://dx.doi.org /10.19044/esj.2018.v14n21p45.

Ndam N, Ewusi BN. 2000. Management Plan for Prunus africana on Mount Cameroon. Limbe Botanical and Zoological Garden. Mount Cameroon Project. Limbe. 46 p.

ONADEF. 2000. Rapport sur la détermination des aires de répartition du $P$. africana. (Pygeum) dans les provinces de l'Ouest, Littoral et du Nord-Ouest Cameroun.

Ondigui B. 2001. Gestion de Prunus africana : situation et perspectives au Cameroun et ailleurs. Rapport GTZ. 85 p.

Peters CM. 2000. Recherche écologique en vue d'une exploitation durable des produits forestiers non ligneux. Recherches actuelles et perspectives pour la conservation et le développement. FAO. Rome, 2000. p 21- 37.

Unaeze HC, Oladele AT, Agu LO. 2013. Collection and marketing of Bitter Cola (Garcinia kola) in Nkwerre local Government area, Imo State, Nigeria. Egyptian Journal of Biology, Vol. 15, pp 3743.

http://dx.doi.org/10.4314/ejb.v15i1.5

République du Cameroun. 1994. Loi 94/01 du 20 janvier 1994 portant régime des forêts, de la faune et de la pêche, 1 à 12 p.

République du Cameroun. Décret $\mathrm{N}^{\circ}$ 2009/2272/PM du 18 décembre 2009 portant création du parc national du Mont Cameroun.

Takere J. 2001. Community management of Prunus africana in the Mount Cameroon region, Cameroon. A preliminary report for MCP (GTZ) Buea-Cameroon and International University of Applied Sciences Eberswalde-Germany.13p.

Tassé B. 2006. Impact écologique de l'exploitation de l'écorce de Prunus africana (Hook.f.) Kalkman dans la région du Mont Cameroun cas de la zone Bokwaongo-Mapanja. Mémoire d'ingénierie : Faculté d'Agronomie et des Sciences Agricoles, Université de Dschang. 113p.

Tchouto P, Mbeng H, Lehrer B. 2014. Monitoring and evaluation report of Prunus africana harvesting activities in Block 1 during 2013, Mount Cameroon National Park PSMNR-SWR: Buea.

Tonye M, Stella A, Ndam N, Blackmore P. 2000. State of knowledge of Prunus africana (Hook. f.) Kalkman. Report established for Central Africa region at program for the Environment (CARPE). Washington Dc. 82 p.

WCMC. 2000. Analyse des données UNEPCITES Trade Data base, Net Trade Report.

Yankam S. 2013. Analyse de l'impact de la gestion actuelle de Prunus africana (Hook. F.) Kalkman au Mont Cameroun (Région du Sud-Ouest Cameroun). Mémoire d'Etudes Supérieures Spécialisées (DESS) en Aménagement et Gestion intégré des Forêts et Territoires tropicaux. Université de Kinshasa. 32 - 38 p. 